\title{
The Non-Traditional Practice of Professional Student CLUB TO CONNECT THE BUSINESS WITH THE ENGINEERING STUDENTS OF UNIVERSITY OF RUSE
}

\author{
Yordanka Dimitrova, Yuliyan Dimitrov
}
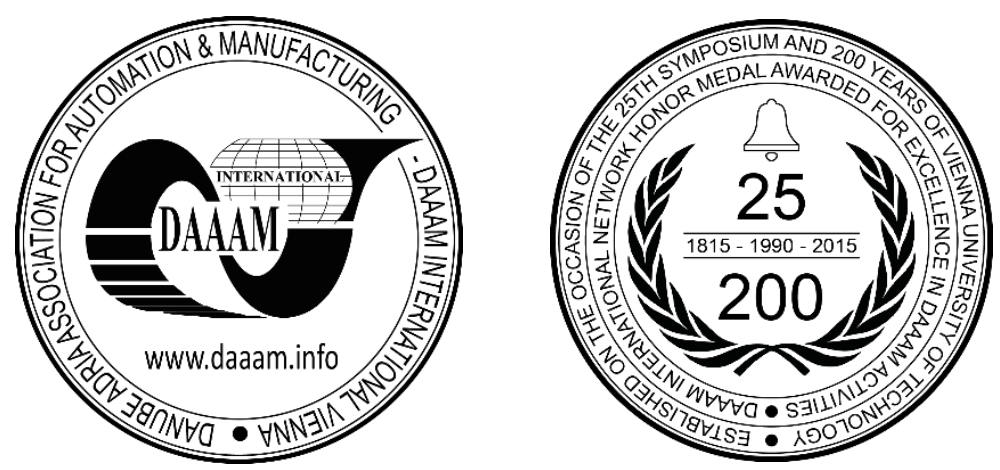

This Publication has to be referred as: Dimitrova, Y[ordanka] \& Dimitrov, Y[uliyan] (2018). The Non-Traditional Practice of Professional Student Club to Connect the Business with the Engineering Students of University of Ruse, Proceedings of the 29th DAAAM International Symposium, pp.1032-1037, B. Katalinic (Ed.), Published by DAAAM International, ISBN 978-3-902734-20-4, ISSN 1726-9679, Vienna, Austria DOI: $10.2507 / 29$ th.daaam.proceedings. 147

\begin{abstract}
The report presents an unconventional practice for professional student club. In Department of Mechanics, Machine Elements and Engineering graphics in University of Rousse, has been created and actively working with students "SMART in CAD" club. In the club, the students solve real practical problems in designing parts of machines. Only interested students are members of the club. During their visits to the club students learn the practical knowledge that is most needed for young professionals. In recent years, there has been a persistent tendency of lack of quality young engineering professionals in CAD systems, with companies giving alarm signals that they can not connect with active students to make lasting contacts. This problem is increasing annually due to the decrease in the number and quality of students in engineering specialties. At this challenging moment, the club plays a major role in raising students' skills as designers and conducting meetings between interested employers and more prominent engineers. The report presents the organization and work of the club, the benefits for students, the nontraditional tasks it performs and the results achieved in favor of the students and the engineering companies with whom the permanent contact is maintained.
\end{abstract}

Keywords: student club; CAD systems; engineers; student; training

\section{Introduction}

The main role of professional clubs in universities is to support talented and ambitious and active students with different talents in the fields of sport, art and science. In these clubs, students develop their talents and expand their knowledge in the areas they are interested in. Clubs have contacts between people with the same professional interests and social causes. But another person in the professional clubs is presented in this report.

In addition to traditional activities, it is shown how a club can be useful for its members - students, helping to make better contacts with interested employers. Thus one member can decide on further career development and professional realization. 


\section{National problem with the lack of engineering specialists.}

In engineering education in Bulgaria there have been divergent tendencies for more than a decade. There is growing interest in business to highly qualified specialists in all areas of engineering but at the same time young people increasingly see their future in this profession. Engineering education implies a high level of basic fundamental training and specialized knowledge and experience tailored to the requirements of professional guilds. Besides the standard ways of teaching in universities, it is necessary to apply modern and non-traditional practices for further training of students. This is a specific academic task that all universities decide differently [8],[10],[11].

The requirements for engineers' competence are large and constantly changing due to the changing work environment due to technical development and modernization of production. This dynamic environment has specific requirements for engineers with which universities in Bulgaria and Europe have to take into account in the training processes (Table 1).

\begin{tabular}{|c|c|}
\hline $\begin{array}{l}\text { Characteristics of the engineers' work } \\
\text { environment }\end{array}$ & Requirements for engineers \\
\hline Globalization of production & Professional skills \\
\hline Increase the variety of products & Creative thinking \\
\hline Time reduction due to innovation & $\begin{array}{l}\text { Adequate communications from } \\
\text { scientific and technical issues }\end{array}$ \\
\hline Increasing the complexity of technical systems & $\begin{array}{l}\text { Responsibilities and actions in } \\
\text { international and intercultural contexts }\end{array}$ \\
\hline New and ever-evolving markets & Diversity \\
\hline $\begin{array}{l}\text { Overloading the environment by } \\
\text { human activity and resource protection }\end{array}$ & $\begin{array}{l}\text { Interdisciplinary } \\
\text { knowledge }\end{array}$ \\
\hline Demographic changes & Lifelong learning \\
\hline
\end{tabular}

Table 1. Particularities of the training process of engineers.

The problem now on the labor market for engineering professionals is the high requirements of companies and the real possibilities of engineering students (Figure 1). Modern companies are equipped with state-of-the-art CAD-CAM-CAE software and software for design, production and analysis, and expect students to work with them. But reality shows that these expectations are not covered by young engineers [7].

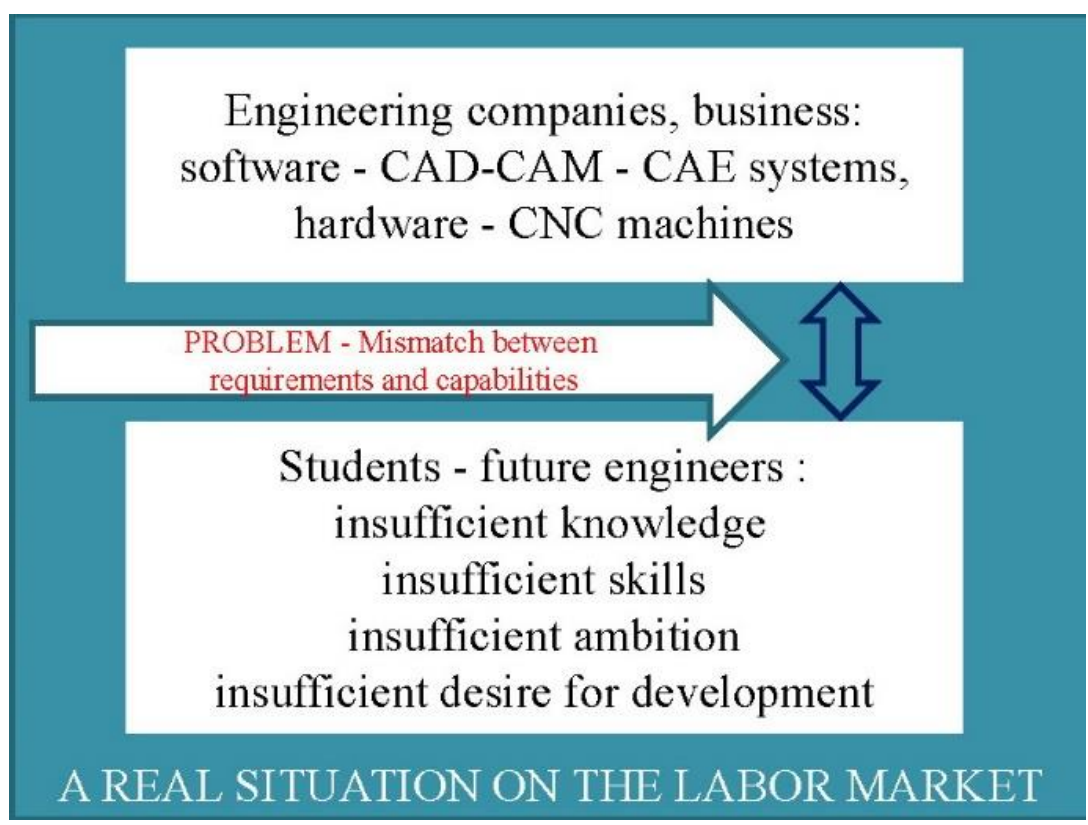

Fig. 1. Figure of the labor market situation for young engineers.

Because of the large and constantly changing requirements and other objective factors, the number of young engineers prepared by the Bulgarian universities is decreasing. The main reasons are [12]: 
- Reduction of the number of candidates in engineering specialties;

- Reduces the number of graduates at national level;

- The number of migrant Bulgarian families in search of work outside the country is increasing. They leave Bulgaria and their children with them (potential students).

- The reluctance to choose training in engineering specialties by the candidate students due to overlapping the opinion of a more difficult learning process.

- The reluctance to choose training in engineering specialties by prospective students, due to overlapping the opinion of low pay in the firms of the hired engineers.

All of these factors lead to a reduced number of graduate engineers. The lack of a sufficient number of well-trained engineers and technicians makes it difficult for foreign investors to expand. This also affects the economic development of certain areas and the intentions of foreign investors. Prior to investing in Bulgaria, foreign investors are exploring not only the economic and financial conditions for the region that they have identified for investment but also the availability of trained specialists for their work. Another major problem for young engineers is that the acquired knowledge at universities does not meet the practical requirements and needs of companies. It is therefore necessary to address universities with greater attention to engineering students, using nontraditional training practices. In particular, work more with interested and more advanced students who show interest and persistence and make contact with these students with companies. A basic requirement of today's business environment is that engineers can use and work with advanced CAD systems. Universities receive basic skills to work with CAD systems depending on curricula, and for other students there are other ways to improve - self-study or participation in specialized courses, e-learning courses or clubs at the university [9].

\section{Professional Student Clubs at the University - an opportunity to upgrade students' knowledge}

In addition to the regular process of student education, universities have a number of opportunities for students to improve their knowledge. Such opportunities are self-training, paid paid courses and or profiled student clubs. For selflearning, the student must be very motivated and spend very well his spare time, real student life shows that this is very difficult for modern young people. Another possibility to raise the knowledge of engineering students outside of regular student courses is paid specialized courses, however, which in most cases require the payment of large fees. Another option is membership in a student professional club, which is voluntary and free of charge [1,3].

In recent years, in the Department of Mechanical Engineering, Machine Elements and Engineering Graphics, there was an idea for the creation of a professional club at the University of Ruse under the auspices of the Department. The idea of setting up the club was to help more active and inquisitive students enter more technically in the technical field of automated design processes with CAD systems, which is a topical issue with the requirement of advanced training [2,4] .

Another main reason for the establishment of the club was the constant contact of colleagues from the department and representatives of machine-building companies from the region. These contacts exchanged information about company problems in their technical work and staffing. Recently, the worrying tendency for the lack of engineering staff shared with firms has intensified [13]. As can be seen from Figure 2, it is provisionally demonstrated that there are good contacts between companies and university lecturers and between teachers and students, but there are no such contacts between students and companies who are future employers. Thus, students do not receive real information from the companies themselves, where they would work after completing their education and under what conditions. There are no direct contacts between students and employers. Students are unclear about the conditions they expect when they will be recruited after their studies. This uncertainty about working conditions, requirements, obligations, entitlements and pay leads students to choose other areas of realization. Due to this fact, lecturers from the department decided to work on solving this problem by helping to improve the contacts between the companies and the students.

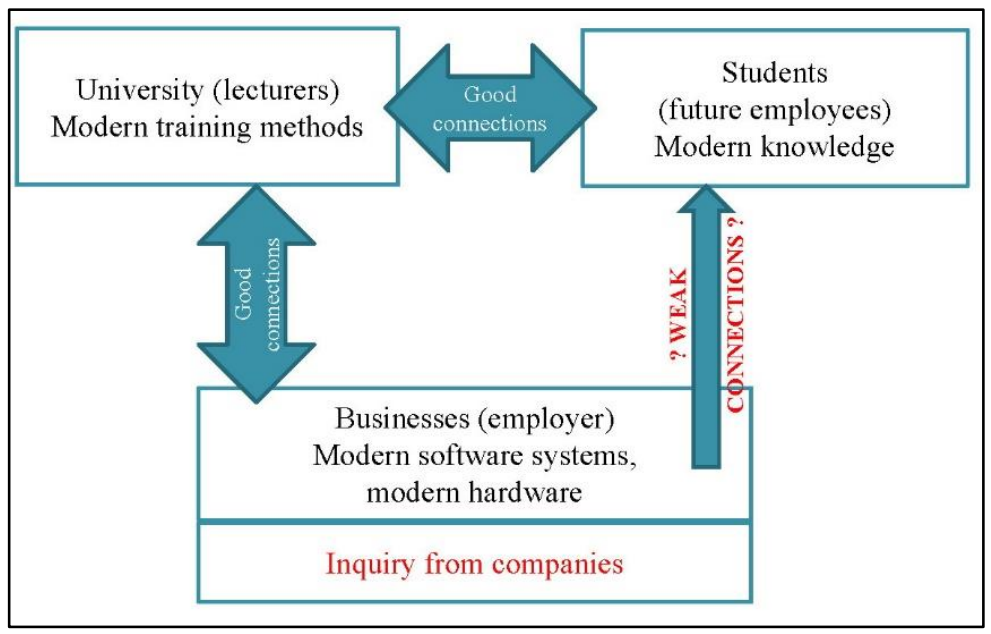

Fig. 2. Relationships and connections between business, university and students. 
Based on years of research in the Department of Mechanical Engineering, Machine Elements and Engineering Graphics during the work with the students, in September 2017, a study was carried out among the students from the engineering specialties in the 2nd and 3rd courses at the University of Ruse about the idea of a professional student club.The results of the survey showed approval for the idea of the club, with about 30 students saying they would be members if it was created. Because of these approved research results, the department decided to create the club. In October 2017, a professional club "SMART in CAD" was established at University of Ruse [5].

Founders were lecturers from the department and 10 students from the engineering specialties at the university. The original idea is for the club to have no mass character, but to work only with individual ambitious and interested students. Meetings are voluntary and with uninterrupted visits that are not related in any way to the assessment of knowledge during the regular learning process.

The main objectives of the club are:

- To unite current and future members of the Club with interest in machine science and engineering design.

- To organize different types of events in the field of training and work of students with CAD systems (computer design systems).

- To enhance the technical culture of club members by conducting discussions, training and consultations on practical engineering issues.

- Improving skills to develop constructive documentation using state-of-the-art technologies - engineering analyzes, technical schemes, 2D and 3D drawings using CAD systems.

- Meetings of representatives of engineering companies and employers with members of the club.

Since its founding, club members have been students, future engineers from mechanical, transport and agricultural faculty. The club has a computer room provided by the university, with licensed engineering software - SolidWorks, Autodesk AutoCAD, Autodesk Inventor. Students can learn and work seamlessly with some of the most used engineering programs used by engineering companies in Bulgaria.

\section{Professional Club "SMART in CAD" - a solution for closer links between business and students.}

The established club does not only improve the technical skills of students in a certain direction, as do the other student clubs. Great attention is paid to improving and strengthening the club members' contacts with their future employers machine building and engineering companies in the region. For the efficiency of the club's work, one can determine the benefits it provides to its members with respect to other students.

\subsection{Voluntary membership and a small number of members.}

There are many formal meetings and seminars with employers in universities to improve links between employers and students (Career Guidance Days, Employer Days, National Career Days). However, the result is not good due to the official nature of the events. Students view them as obligatory and formal, which changes their attitude towards negativity and disinterest. There is a Center for Career Development at the University of Ruse, but for various objective reasons the students do not ask for information about it. The situation in the student club is quite different - there are unintentional conversations for technical problems related to the learning process and practical problems. Student-teacher relations are free, due to the fact that this is not a purely learning process. The small number of members adds a more intimate and relaxed environment, providing a PC workspace for each member. There is an opportunity to address the issues and questions of each member of the club. If desired, club members work with their own laptops. The presentations are voluntary and not obligatory.

\subsection{Lack of material benefit (no material rewards, only intellectual).}

Membership is not tied to funds and payment of membership fees. Each meeting is attending training on a particular topic or issue. No prize for attendance. Membership is not of a competitive nature. The benefit to club members is the useful information about machines, machine elements, use application software, and more.

\subsection{Getting knowledge and skills related to the practice (discussing and solving concrete practical problems).}

Students understand that the club can ask about any practical problems they have encountered at home or on family businesses and acquaintances. Such issues are discussed in front of everyone and their decisions are useful to everyone present. All the topics in the club are practical. Specific questions and real projects are being presented to companies involved with the department's lecturers. In individual cases, company constructors present their solutions and problems during their work in the company. In the spring of 2018, a guest at the club was a representative of "Dito Metalworks" Ltd. (from Ruse, Bulgaria), on which were presented projects of the company and particularities of the design work [14]. Talks are held with large machine-building companies from the region (Sparky Ruse, TM Technology JSC) for their presentation in the club. 


\subsection{Relationship between interested employers and active students.}

At least one semester meeting between employers from different companies and students from the club in an informal environment is organized. This avoids the formalisation of communication, which gives more confidence and peace to students to ask questions that interest them. Students explain their requirements and expectations as future employees.

\subsection{Discussing problems in recruiting young engineers - connections between employers and students}

Club meetings discuss students' attitudes to their first job, what are the expectations of working time, working conditions and salary. At the same time, such talks are held with employers' representatives, what they offer to graduate students as their first job. It has been found in these conversations that there are very large differences between the wishes of both sides. That is why discussions are taking place to bring the requirements of the companies and the wishes of the students closer. This achieves a more realistic picture of the current state of the labor market and increases the likelihood of more contact between students and employers.

Negotiations are being held with companies to offer students acceptable conditions for practicing, paid internships, part-time work, or pre-contracting engagement of young engineers with the company. The aim of all these activities is to improve the students' practical skills and to improve the relations between students and companies. Students who are members of the club have many advantages over students in the regular training process. These advantages are shown in Table 2 .

\begin{tabular}{|c|c|}
\hline Regular learning process & Student club activities \\
\hline Certain topics for study & Any topics that are exciting for students \\
\hline Presence tied to evaluation and testing & Voluntary presence, no engagement and pay \\
\hline Emphasis on theoretical tasks and problems & Focus on practical tasks and problems \\
\hline Contacting mainly with lecturers & $\begin{array}{l}\text { Contacting lecturers and representatives of engineering } \\
\text { companies }\end{array}$ \\
\hline Scheduled attendance, scheduled lectures & $\begin{array}{l}\text { Club meetings are scheduled, but members can contact the } \\
\text { Viber, e-mail, Messenger, Facebook }\end{array}$ \\
\hline
\end{tabular}

Table 2. Benefits of student club membership compared to the regular learning process.

Expansion of the contacts with the engineering companies from the region and increasing the connections between them and the students is envisaged.

\section{Conclusion}

Thanks to the established professional student club by the lecturers, this year saw an increased interest in the use of CAD systems by the students. The students' requests for practical engineering problems are increasing. Students have become more active in solving tasks during the learning process with CAD systems. Students in the club meet directly with representatives of companies who might be their employers.. A fact that brings more students closer to the demands of their future employers. All this is done in the name of the students after long-term studies of the lecturers from the department of Mechanical Engineering, Machine Elements and Engineering Graphics, of the specific learning process and additional forms of education.

\section{Acknowledgments}

This paper would not be possible without the assistance of my colleagues from the department and the assistance of the private companies with which the Department of Mechanical Engineering, Machine Elements and Engineering Graphics in University of Ruse.

\section{References}

[1] Dimitrov, Y.(2016). Contemporary approaches for students' education in the area of design and application of CAD systems. Journal Management \& Sustainable Development, Vol.1, ISSN 1311-4506.

[2] Dobreva, A \& Dimitrov.Y.(2012). Increasing the efficiency of the study process through extracurricular activities with students. Journal Management and Sustainable Development. Vol.1, pp 27-30, ISSN 1311-4506. 
[3] Dobreva, A. \& Haralanova, V. (2013). Measuring and Evaluation in Machine Science and Design Education, based upon Diagnostic Research.// Procedia - Social and Behavioral Sciences, WCLTA, Brussels, 3rd World Conference on Learning, Teaching and Educational Leadership. Vol.93, pp. 1190-1194, ISSN 1877-0428. (SJR rank: 1 /2013, Scopus)

[4] Kamenov, K.; Dobreva, A \& Ronkova, V.(2016). Interactive Technologies and New Teaching Models in Engineering Design based upon Multimedia Tools and Mobile Applications.// Fullpapers E-Book/ 4th World Congress on Education Research (WCER2016), 2016, Vol.1, pp. 90-95, ISSN 2258-6987. (SJR rank: 1 /2016, Google Scholar)

[5] Ronkova, V.; Dobreva. A.; Kamenov, K.; Dobrev, V \& Dimitrov, Y.(2016) Increasing the efficiency of the study process through imroving the communication activities between students and lecturers. Journal Management and Sustainable Development,Vol.59, pp. 77 - 82, ISSN 1311-4506.

[6] Kamenov, K.; Dobreva, A. \& Ronkova, V.(2017). Advanced Engineering Methods in Design and Education.// Material Science and Engineeering, IOP Publishing, 2017, pp. 33 - 37, ISSN 1757 - 8981. (SJR rank: 1 /2017, IOP)

[7] Shevtshenko, E., Karaulova, T., Igavens, M., Strods. G., Tandzegolskiene, I., Tutlys. V.; Seyed., T. \& Kuts, V. (2017) Dissemination of engineering education at schools and its adjustment to the needs of enterprises. Proceedings of the 28th DAAAM International Symposium, pp.0044-0053, ISBN 978-3-902734-11-2, ISSN 1726-9679, Vienna, Austria

[8] Kharin, K., Kuvshinov, S. \& Pryanichnikov. V. (2016). The use of three-dimensional visualization on the basis of the Motionparallax 3d technology in the development of complex technical devices and training of engineers. Proceedings of the 27th DAAAM International Symposium, pp.0338-0343, ISBN 978-3-902734-08-2, ISSN 17269679, Vienna, Austria

[9] Moravcikova. J. (2016). The possibilities of exploitation of e-learning in technology-oriented courses. Proceedings of the 27th DAAAM International Symposium, pp.0136-0141, ISBN 978-3-902734-08-2, ISSN 1726-9679, Vienna, Austria

[10] http://computerworld.bg/41686_nedostigat_na_tehnologichni_i_inzhenerni_specialisti_problemi_i_resheniya

[11] https://www.bia-bg.com/focus/view/21464/

[12] https://forum-sever.com/2017/06/20/доц-руси-минев-недостиг-инженери/

[13] https://www.mon.bg/upload/13809/06_Senya_Terzieva_HTMU.pdf

[14] http://ditometal.eu/ 